\title{
KANT ON RELIGIOUS INTOLERANCE
}

\author{
Joel Klein ${ }^{1}$ \\ (Universidade Federal do Rio Grande do Norte / \\ Alexander von Humboldt Fellow)
}

In order to understand the way Kant deals with the topic of religious intolerance we must reconstruct three aspects of his theoretical and practical philosophy, namely, the principle of non-coercive force of religious belief, the principle of truthfulness regarding matters of faith, and the criteria of publicity regarding public affairs, which includes matters of faith. These aspects determine how the state and politics may and should deal with religion, particularly with problems of religious intolerance. Each principle will be thoroughly presented and analysed below.

\section{The theoretical and practical non-coercive force of religious belief}

Following Kant's positions, we could say that the only way to have peaceful coexistence between different peoples with distinct historical religious beliefs is by means of a critique of pure reason that establishes, once and for all, what an object of possible knowledge is and how it differs from an object of belief or faith. One of the main consequences of Kant's critical philosophy is that religion and everything related to it are incapable of coercive force, both theoretical and moral.

The theoretical non-enforcement regarding objects of religion is due to a qualitative rather than a quantitative distinction between one statement endowed with "truth-value" and another limited to merely "belief-value".

1 jthklein@yahoo.com.br

Philosophica, 51, Lisboa, 2018, pp. 25-38. 
While judgments regarding God, the immortality of the soul, and freedom aspire the status of theoretical knowledge, they have to be considered simply false when compared to other theoretical and scientific assertions. The only possibility for religion to gain any rational legitimacy is when its theoretical aspirations are restricted to the field of belief. That is one of the meanings of Kant's well-known assertion: "I had to deny knowledge in order to make room for faith" $(\mathrm{KrV}, \mathrm{B} \times \mathrm{xx})^{2}$, which also means that objects of faith should not aspire to be considered knowledge.

According to the Transcendental deduction of categories, being an object of possible knowledge means to satisfy requirements of the legitimate operation of our cognitive faculties. So, for example, the concept of causality must be applicable to any event, which is specifically located in a determined space and time. In this sense, it is a condition of the use of our categories that they can only be applied to something that may be given (the phenomenon) or constructed (in the case of the objects of mathematics) in our intuition (cf. $\mathrm{KrV}$, B147-149). However, by being given in intuition the object would already be subordinate to the formal conditions of our sensibility and to what constitutes the form of the phenomena, namely, the formal structure of nature given by the categories applied to the sensible forms of space and time. Consequently, there are two options. On the one hand, an event/object is given in the intuition and it can necessarily be known as being caused by an earlier event/object and is therefore not selfcaused. On the other, said event/object cannot be given in intuition and, in this case, it is not an object of possible knowledge. In the case something calling itself God appears in our intuition, then we could be sure that it cannot be God, because then we could discover its cause and then it would cease to be an uncaused being. If, on the other hand, God could not be given in our intuition, then he could not be considered an object of possible knowledge.

Therefore, Kant's transcendental philosophy establishes that God, freedom and the immortality of the soul are objects that remain outside the field of our possible experience and so they can ever be considered objects of our possible theoretical knowledge. This delimitation does not arise from an exhaustive analysis of the objects effectively in the field of our possible experience, which is potentially infinite. A critique of pure reason does not evaluate objects, but the faculty of reason itself (cf. $\mathrm{KrV}$, B xxi-xxix). Moreover, based on the analysis and evaluation of the way our

2 All translations of Kant's works are quoted from The Cambridge Edition of the Works of Immanuel Kant and follows the rules of the Academy edition. 
faculties of knowledge work, Kant states that God could never be an object of possible knowledge.

We must also distinguish between the objects of belief and those of opinion, as they have distinct natures. Objects of opinion are not yet objects of knowledge, but they could become so, were certain conditions to be fulfilled, such as, being empirically determined by our intuition. On the other hand, objects of belief or faith can never be objects of theoretical knowledge, because, by definition, they can not be objects inside the structure of nature. So, the existence of alien life on other planets is an object of opinion, which might be more or less plausible, but, in principle, could be proven if we were to have empirical intuition of these beings or if we found strong evidence of their existence. On the other hand, the existence of God is not something that could ever be an object of our intuition. Therefore, God can not be an object of opinion.

Moreover, religious belief can not call for practical enforcement, either form an ethical nor a juridical perspective. Religious beliefs can neither enforce their judgments by relating them to the foundation of morality nor as a consequence of moral law.

Regarding the level of the foundation of morality, religious morality is based on the concept of perfection, from either a theological or ontological perspective. Those theological versions of perfection state that morality takes place when agents try to fit their actions to a model derived from the concept of perfect divine will. In this case, because we cannot intuitively access this concept of perfection, we have two possibilities. Firstly, we might conceive it from the point of view of what we consider to be our noblest nature, the concept of good will, but then we fall into a vicious circle (because we extract from this concept what we already have put into it). Or, on the other hand, we would devise a concept of perfection based on divine will which is "still left to us, made up of the attributes of desire for glory and dominion combined with dreadful representations of power and vengefulness, [which] would have to be the foundation for a system of morals that would be directly opposed to morality" (GMS, AA 04: 443). The version based on an ontological concept of perfection also suffers from the problem of circularity. In this situation, Kant points out that the agent must already desire a model so that they may be constrained by it. However, there is no reason that the agent must feel constrained by it in the first place. Therefore, choosing between different models of perfection becomes a matter of personal or cultural preference. For this reason, such models of ontological perfection can only provide us with hypothetical imperatives and heteronomy (cf. GMS, 04: 444). So, the religious beliefs 
related to those hypothetical imperatives have no practical enforcement in the strict sense of morality.

Regarding the consequential level of morality, religious beliefs have also any practical enforcement. It is well known that Kant tries to relate his moral theory to a moral religion. This topic of rational religion or religion in the boundaries of simple reason is a highly complex and subtle issue that is beyond the scope of this paper. What does matter here is that Kant still holds that belief cannot be mandated, so religious beliefs cannot be constrained by the categorical imperative. In other words, religious belief does not follow as an immediate consequence from morality and autonomy. Moreover, this non-consequential character has to be understood in two senses. Firstly, from the point of view of moral theory, i.e., the consciousness of the moral law does not immediately involve the consciousness of the existence of God, nor the immortality of the soul (the foundation of almost every religion). Secondly, from the point of view of moral practical agency, the categorical imperative does not dictate any universal religion or religious belief. Moreover, it does not make sense to speak about moral universalizability or the necessity of belief because morality only deals with things that are under our control. In other words, the same thing that happens with pathological love (cf. GMS, AA 04: 399) occurs with belief, namely, they can not be mandated (cf. Log, AA 09: 74). Therefore, religious belief is not subject to ethical enforcement, because, on the one hand, it does not pass the test of universalizability established by the categorical imperative. On the other hand, the act of believing is not subject to our will.

Also from the point of view of Kant's theory of law, religious belief should not be subject to any legal enforcement. Religious belief is always grounded in or involves a concept of good and happiness that cannot be universalized by the categorical imperative of right, which states: "act externally that the free use of your choice can coexist with the freedom of everyone in accordance with a universal law" (MS, AA 06: 231). Freedom is the only basis for right and no religious belief can legitimately claim to be institutionalized by law. Therefore, the laws of a republican state, which is the only truly legitimate, can never be drawn up and established based on a particular concept of religious perfection nor good life, because those concepts already presuppose a concept of good or happiness, which is the ground for a despotic state (cf. TP, AA 08: 290).

Moreover, "[d]uties in accordance with rightful lawgiving can be only external duties, since this lawgiving does not require that the idea of this duty, which is internal, itself be the determining ground of the agent's 
choice" (MS, AA 06, 219). It is not up to law to establish a duty to believe, because law is intrinsically related to the faculty of coercion by way of pathological determination grounds which are directed to external actions. While ethics is directed to ends and the intention of the actions, right should be restricted to externally conceived actions. "Now, I can indeed be constrained by others to perform actions that are directed as means to an end, but I can never be constrained by others to have an end: only I myself can make something my end." So, external "coercion to ends (to have them) is self-contradictory" ( $M S$, AA 06,381$)$. Having a belief is not the same as choosing or having an end, but both are limited merely to actions qua internally conceived actions. In this sense, law can obligate individuals to attend church services or even to pretend to believe in some historical religion, but it can never oblige individuals to truly accept any religious belief. Therefore, the state assumes an unrightful path when it establishes laws imposing religious beliefs. Such coercion can only promote falsehood and concealment and turn religious belief into something hateful. This is exactly the position of Kant regarding Christianity when it tries to add some sort of authority (cf. EaD, AA 08, 338).

In the same way that Kant sees Christianity, we can state that every matter strictly related to religious belief must be approached with a "liberal way of thinking", i.e., we can freely argue about matters of religious beliefs and hope that "the effect of its doctrine, through which it may win over the hearts of human beings when their understanding has already been illuminated by the representation of their duty's law." (EaD, AA 08, 338) But this "winning of other's hearts" can only be hoped for as a "free" consequence insofar as this belief does not contradict theoretical and practical knowledge and even has the positive effect of promoting them. So we have already arrived at the topics of the next two sections, namely, the principle of truthfulness and publicity in matters of religious belief.

\section{Truthfulness and religious belief}

On the miscarriage of all philosophical trials in Theodicy is an enlightening essay about the issue of truthfulness in religious beliefs. It starts by calling for all of those who argue for and against the possibility of theodicy to present their arguments in the court of reason. The final judgment follows, in general lines, the arguments presented above, namely that we can neither theoretically prove nor disprove the possibility of a theodicy, which means that it, as a highly interconnected topic of religion, is neither an object of theoretical nor practical knowledge, but only of belief. 
After concluding that theodicy "does not have as much to do with a task in the interest of science as, rather, with a matter of faith" (MpVT, 08:267), Kant goes further and deals with the issue of lying and truthfulness regarding the matters of religious belief. He differentiates between formal and material truthfulness. Material truthfulness implies taking care not to commit an injustice or an error, while formal truthfulness means having the consciousness of taking every precaution in a particular case. After that Kant points out a fundamental distinction between telling a lie and making a false statement. "Truth" and "falsity" are logical aspects of judgment, while "truthfulness" and "lying" deal with the attitude of agents (cf. $M p V T$, AA 08: 268). From this point of view, Kant posits that someone may offer a false judgment without realizing it, but it is impossible to tell a lie without being aware of it. The lie and the truthfulness are attributes of agents' attitude towards their own judgments, which always reflects their nature as free beings. Both telling a lie and being truthful are the actions of self-aware, free beings; otherwise we could no longer speak of free agents or any kind of responsibility. In this case, Kant says, anyone who "lies" to themselves may, with time, intensify this habit when they benefit from it, but a lie can never be turned into a mere false judgment. In other words, in a strict sense, we can never lie to ourselves without knowing it. Therefore, lying to ourselves means being hypocritical.

Now, regarding maters of religious faith Kant asserts that, first of all, it is absurd that anyone profess to believe in God or religious dogmas without having made a thorough self-examination of their own consciousness (cf. MpVT, AA 08: 268). Secondly, and more drastically, someone who states that their belief is actual knowledge is also telling a lie. Denying that religious belief is a totally distinct type of holding-to-be-true than practical and theoretical knowledge is also a lie, since it is part of the formal conscientiousness of truthfulness to recognize that belief and knowledge are two different kinds of holding-to-be-true (Fürwahrhalten). Kant clarifies his position by interpreting biblical stories, specifically the debate between Job and his friends (MpVT, AA: 08:265ff.). In these passages we can see that those who arrogate to themselves the status of representing God's interests are not only mistaken, but they are lying to themselves and to God. They are, therefore, committing an immoral act.

In a similar vein, we can understand Kant's evaluation of the story of Abraham (see $S F$, AA 07: 63n.). However great and impressive some external phenomena may appear, we must have sufficient sincerity to confess that they cannot sustain absolute certainty since they must be submitted to theoretical or practical objective principles. Our reason has principles that 
we can neither deny nor pretend not to listen to. So, even if Abraham in fact had heard a voice coming from the sky telling him to murder his son, he knew that God could never order such an act. That is why Kant claims that Abraham should have said 'God would never order such a thing'. How did Kant come to this position? Because, on the one hand, religious belief is independent of the practical and theoretical domains of reason, but this does not mean that it can make judgments that contradict principles of pure reason. For Kant, this acknowledgment is not limited to the philosopher, but is already present in the consciousness of common human reason.

The truthful recognition that religious belief is not subject to certainty and constitutes neither theoretical nor practical knowledge has nothing to do with the importance of the belief to the agent. Religious belief can be as psychologically and socially relevant for a person as mathematics, science or even morality. ${ }^{3}$ However, despite this personal and subjective importance, everyone must recognize and actually know that religious belief can obligate no one, neither themselves, nor others. In other words, every one is aware in some degree that their religious belief, however invariable and stable, is distinct from any kind of knowledge, i.e., it is a kind of holding-to-be-true that cannot be subject to any kind of imperative (cf. $S F$, AA 08: 42). Since the formal and material criteria of truthfulness is at everyone's disposal, anyone can be aware of the immorality of all kinds of religious persecutions or of "casting religious hatred upon others" (cf. $V$-Mo/Collings, AA 27, 453ff.). Therefore, Kant sustains that, in order to be truthful, each believer and every religious institution must acknowledge that their tenets have neither theoretical nor practical certainty. In other words, it is a component of sincerity and truthfulness of character to acknowledge that we do not know objects of religious belief and, therefore, that there are no theoretical or practical grounds for any kind of religious persecution.

\section{Publicity as condition for freedom of religion}

According to Kant's practical philosophy, freedom of religion depends on three different ways in which religion must be related to publicity: 1) the impossibility of particular historical religious maxims passing the test of publicity that is required by the positive transcendental principle of public law; 2) the right to freedom for the public use of reason concerning

\footnotetext{
3 Regarding the invariability that a rational religious belief may have, see WDO, AA 08: 141.
} 
issues of religion and, finally; 3 ) the assurance and promotion of that freedom at two levels, firstly through the guarantee of the legal conflict of faculties and, secondly, by fostering public education that teaches the meaning and the exercise of publicity regarding religious themes at school.

The first aspect of publicity in issues of religion refers to the impossibility of any strictly religious principle passing the test of the political-juridical principle of publicity which is understood to be the transcendental principle of public law. So, we have a priori a moral-political criterion for knowing whether political action may be considered justified, namely: "All actions relating to the rights of others are wrong if their maxim is incompatible with publicity" ( $Z e F$, AA 08: 381). If a particular religious group in a pluralistic country tries to change the laws of the state, or even the political government, in accordance with its religious principles, for the sake of its political or financial interests, then, according to Kant, is easy to see how their goals will fail if publicly announced. Other religious and non-religious groups would disagree with such a policy and would block these changes. In other words, the only way such a goal could expect to be successful would be if it were carried out in silence. Therefore, the maxims that would fail to achieve their ends when publicized could not be harmonized with the principle of publicity.

However, this 'negative' criterion of publicity is not sufficient for a political maxim to be considered morally good, since it could still be publicized when a group is sufficiently powerful to impose their moral world-view upon others. In order to avoid this kind of problem, Kant advances a positive criterion for testing the legitimacy of political action, namely "all maxims which need publicity (in order not to fail in their end) harmonize with right and politics combined." (ZeF, AA 08: 386). The positive formulation states that when an end can be achieved only upon being publicly announced, then it can be rationally accepted by all. The intrinsic characteristics of religious beliefs make it impossible for them to pass the criteria of the positive principle of public law and to expect to be rationally accepted by all. So, for example, to "claim universal validity for a dogma (catholicismus hierarchius) involves a contradiction: for unconditioned universality presupposes necessity, and since this occurs only where reason itself provides sufficient grounds for the tenets of faith, no mere statute can be universally valid" ( $S F$, AA 07: 49). Thus, everyone should agree to the freedom of religious worship, whether or not they believe in any historical religion. But not everyone might agree to grant the right of freedom of religious worship to some historical religion (sometimes Kant call this ecclesiastical faith (cf. $S F$, AA 07: 42)) that publicly expresses its intolerance 
or its intention to politically impose its ends on others. It would be impossible for an atheist or even an enlightened religious citizen to accept that this historical religion might have the right to turn its dogmas into law. So, freedom of religious worship has a moral limitation defined by publicity, a limit of right. Therefore, issues concerning strictly religious matters should be kept out of politics. Here we can see the republican branch of Kant's moral philosophy, namely, that we do not have nor should we put up with intolerant historical religions (RGV, AA 06: 96).

The second aspect of the relationship between religion and publicity concerns the right to freedom for a public use of reason on issues of religion and the legitimacy and importance of the legal conflict of faculties. Publicity can be defined as the condition through which something can be publicly spoken; it is the capacity to manifest out loud our own opinion (either in speech or in writing). Publicity is opposed to any limitations on the freedom of speech and to legally or socially forced secrecy about opinions, beliefs and thoughts. Publicity regarding matters of religion means the freedom to make public use of our own reason about matters of religion. In the essay of Enlightenment, Kant focuses chiefly on matters of religion, because, as he states, religious tutelage and religious minority is not just "the most harmful", but it "is also the most disgraceful of all" (WA, AA 08: 41). When a clergyman says "do not argue but believe!" (WA, AA 08: 37), he opens the door to a complete heteronomy of practical reason, which transforms human beings into simple means or things. Human beings become animals wearing a yoke: they become incapable of 'walking confidently' and taking a 'leap over even the narrowest ditch' by themselves. When clergymen say "do not argue but believe!", they are also being immoral: firstly, because they are putting themselves in the position of God's representatives and also, in an arrogant and hypocritical way, as God's interpreters. This goes against the principles of truthfulness and sincerity that are the grounds of all morality. Secondly, said clergymen are taking a path that undermines the fundamental right to self-enlightenment. When a government reinforces this clergymen's immoral posture via legal coercion, then the state undermines its own legitimacy, because "what a people may never decide upon for itself, a monarch may still less decide upon for a people; for his legislative authority rests precisely on this, that he unites in his will the collective will of the people". Therefore, "[o]ne can indeed, for his own person and even then only for some time, postpone enlightenment in what it is incumbent upon him to know; but to renounce enlightenment, whether for his own person or even more so for posterity, is to violate the sacred right of humanity and trample it underfoot" ( $W A$, 
AA 08: 39f.). "Thus the prohibition of publicity impedes the progress of a people toward improvement, even in that which applies to the least of its claims, namely its simple, natural right." ( $S F$, AA 07: 89)

Publicity in matters of religion means that religious issues should be brought to the public space respecting the criteria that guide the freedom of the public use of reason. There are two requirements: that of a specific space and moment and; that of a specific behaviour. So, for example, "a clergyman is bound to deliver his discourse to the pupils in his catechism class and to his congregation in accordance with the creed of the church he serves, for he was employed by it on that condition." (WA, AA 08: 38) In the same way, no one has the right to invade a religious service and question the clergyman during prayer. However, the freedom of the public use of reason guarantees that the clergymen can put forward their doubts and make interpretative suggestions regarding church's orthodoxy when meeting with priests or when taking part in a public debate. Similarly, each individual has the right to publicize or to express their opinions regarding the interpretation of the Bible or other religious matters in books, journals, news or hand-outs. Moreover, the second criterion establishes that the public use of reason requires a certain form of conduct, i.e., it must be performed in the same manner that an erudite person would have done. In other words, the public use of reason, in order to respect the laws of freedom, must be grounded in rational arguments and reject any sophistry that might appeal to unjustified fears or prejudices.

The third way in which religion must be related to publicity is when the state takes part in guaranteeing and promoting the freedom of the public use of reason about religious issues. This state's positive engagement in the enlightenment processes could be questioned (cf. $R G V$, AA 06: 95f.), however, is very important to realize that, for Kant, what must be avoided is the use of force by the state or the imposition of religious enlightenment by means of legal and juridical coercion. This would be the case if someone were be punished for not participating in the public use of reason or for not having ethical ends. This is very different from the state taking positive measures to promote publicity. So, the state must not just stop hindering the progress of enlightenment, but also, indeed, it should promote the same by assuring a 'healthy environment' for the good formation of a moral mode of thought ( $I a G$, AA 08: 26). This positive fostering involves two spheres of institutional support: 1st. the institutional assurance of the freedom of public use of reason, especially by university scholars; and, 2 nd. the public teaching of the principles of publicity to children. 
The first sphere refers to ensuring the legal conflict of faculties at the university (cf. $S F$, AA 07: 29). According to Kant, this means to avoid both material and formal illegality. Material illegality occurs when the state establishes a censorship which blocks the freedom of public use of reason as such, therefore, the capacity of thought as such (cf. WDO, AA 08: 144). On the other hand, formal illegality does not prevent the debate itself, but is grounded on a sort of sophistry, which results in the inevitable defeat of reason and the faculty of Philosophy. So, when there is a legal conflict of faculties inside the university, the parts have no right to appeal either to the government or to the prejudices of the people (cf. $S F$, AA 07: 34n.).

In a legal conflict of faculties Kant believes that philosophy can pose questions to theology. Mostly, however, it can show theology how to coherently use its historical doctrine through the touchstone of a critique of pure reason and the concepts of practical reason. This means, for example, that all historical religions should realize that anthropomorphisms have extremely harmful consequences when they surpass the symbolic representation (cf. $R G V$, AA 06: $64 \mathrm{n}$ ). Another example of enlightenment fostered by the legal conflict between philosophy and theology is that without the moral archetypes provided by pure practical reason, historical religions would become devoid of all moral content (cf. $R G V$, AA 06: 104).

The state can also encourage moral enlightenment within historical religious institutions, not only by allowing but also by promoting the conflict of the faculties. Clergymen, like every other profession working inside the state, are subject to its regulation. This means that the state has the right to demand a good education of those who will work in a house of worship. This education has two aspects: firstly, a good knowledge of the historical groundings of some specific historical religious beliefs (e.g., knowledge of biblical exegesis) and; secondly, an adequate knowledge of the supreme moral principle and the grounds of the republican state (cf. $R G V$, AA 06 : 10). In this way, the state does not interfere directly in the orthodoxy of historical religions, but indirectly by promoting the good moral education of clergymen. It is important to note that this does not constitute a direct intervention of the state in matters of religion, but only a guarantee of the fruitful, legal conflict of faculties. After all, how would this important conflict take place if one of the parties refused to participate? In other words, how would a legal conflict of faculties be possible if one of the faculties withdrew from the university and from the arena of public debate? This posture would reveal a kind of sectarianism that could only undermine the legitimacy of the republican state. Therefore, the state should not interfere 
in the particular affairs of historical religions, but it can and should take two measures: firstly, it must ensure that historical religions do not undermine the moral values upon which the state and law are grounded (the idea of equal freedom) and; secondly, the state has the right to promote the good education of clergymen in order to avoid sectarian education. However, it is not the state itself that takes care of the education of clergymen, but the university, which, Kant argues, must have some autonomy from the state and be set up as a community of scholars organized in a republican fashion. But what can philosophy teach to students of theology? Again, it could teach that any legitimate interpretation of a holy book, such as the Bible, must be symbolic and must be grounded in moral concepts, i.e., that religion must always strive to present the moral law in religious narratives. Another point is the importance of the clear distinction between knowledge and belief and that the latter always presupposes the free acceptance of the believer.

The second sphere where the state may act to ensure freedom of investigation and religious toleration is by including in school curricula the meaning and the importance of the freedom of the public use of reason. Even when the government intends to ensure the legal conflict of faculties at university, an ignorant people corrupted by sectarian clergymen could force an illegal conflict inside society. In order to avoid this kind of social intolerance, the state has the right to intervene and to establish public policy regarding the educational system (cf. $M p V T$, AA 08:269; $S F$, AA 07: 42; TP, AA 08: 288.).

Those external and internal blind professions of faith are related to the topics discussed above, namely, that untruthfulness of religious belief is present in each historical religion that fails to recognize their lack of coercive force, be it theoretical or practical. Public purification of this hypocrisy may occur only when the state takes into its hands the protection of the freedom of the public use of reason. This does not mean that the state should coerce people into believing in some religion. It does mean that the state should not only permit and promote the legal conflict of faculties, but it may also ensure that the principle of publicity is promoted by public education and social life of society. In other words, enlightenment is a process that should be promoted by the state through public education (cf. $S F$, AA 07: 92f), although it cannot be forced or imposed by law. In other words, the state can only protect the enlightenment process of its citizens when it takes into its hands the task of educating the populous about the meaning, the importance, and the use of the public principle of publicity. This pedagogical policy is another condition for the freedom of religion and religious tolerance. 


\section{Final Remarks}

In Kantian Moral Philosophy, freedom is the ground for all legitimate interpersonal relationships, whether ethical, legal, or political. Freedom is also the condition and the limit of issues regarding religion. For this reason, we can say that it is freedom that sanctions religion and not religion that sanctions freedom. In this case, when a clash between freedom and religion takes place, it is religion that has to step aside. Analysing Kant's treatment regarding the theme of religious tolerance, we can see how Kant reconciles aspects of liberalism and republicanism in his practical philosophy. As a liberal, Kant sees that the freedom of religion is an innate right that must be guaranteed by law. However, as a republican, he also realizes that in order this freedom to be real it must be nourished and protected, and the state must therefore take institutional measures in this regard. So, freedom of religion is something that must be accepted by the state, but it need not be extended to religions that fail to grant the same moral right to others.

\section{Bibliography}

Kant, Immanuel (1900ff): Gesammelte Schriften. Hrsg.: Bd. 1-22 Preussische Akademie der Wissenschaften, Bd. 23 Deutsche Akademie der Wissenschaften zu Berlin, Bd. 24 Akademie der Wissenschaften zu Göttingen. Berlin.

— (1992ff.): Cambridge Edition of the Works of Immanuel Kant, Cambridge. 


\begin{abstract}
According to Kantian philosophy, it is freedom that should sanction religion and not religion that should sanction freedom. This thesis is the basic condition for religious tolerance, and it is grounded in three principles that regulate the relationship between politics and religion, namely: the principle of non-coercive force of religious belief; the moral requirement of truthfulness in professions of belief; and, the submission of religion to the principle of publicity. The objective of this paper is to present, explain and justify the application of these three principles towards the notion of religion and to indicate how they might help to understand political and moral issues regarding religious intolerance.
\end{abstract}

Key-words: Freedom - Religion - Intolerance - Truthfulness - Publicity

\title{
RESUMO
}

De acordo com a filosofia kantiana, é a liberdade que deve sancionar a religião e não a religião que deve sancionar a liberdade. Esta tese é a condição básica para a tolerância religiosa, e é fundamentada em três princípios que regulam a relação entre política e religião, a saber: o princípio da força não-coerciva da crença religiosa; o requisito moral da veracidade nas profissões de crença; e a submissão da religião ao princípio da publicidade. O objectivo deste artigo é o de apresentar, explicar e justificar a aplicação desses três princípios em relação à noção de religião e indicar como eles podem ajudar a compreender questões políticas e morais relacionadas com a intolerância religiosa.

Palavras-chave: Liberdade - Religião - Intolerância - Veracidade - Publicidade 